\title{
Integrating Development issues and Innovation elements in Higher Learning Institutions' Curricula a case of a Planning Institute in Tanzania
}

\author{
Article by Judith namabira \\ Ph.D in Management, Texila American University, Tanzania \\ E-mail: jnamabira@texilaconnect.com
}

\begin{abstract}
Successful industrialization helps create employment as it releases labour from agriculture directly and by stimulating the development of modern services. Industrial development has recently taken centre stage in the policy debate in the United Republic of Tanzania. The adoption of the Long Term Perspective Plan (2011/12-2025/26), which advocates for industry to propel the socio-economic transformation envisioned in the TDV 2025, and the Integrated Industrial Development Strategy (2011-2025). The Vision 2025 formulated in 1999 aims at propelling Tanzania from low-income economy to a middle- income economy with a high level of human development, whose economy is diversified and semi-industrialized. The idea is that manufacturing needs to contribute $40 \%$ of the GDP and generate $40 \%$ of all new jobs by 2020. As a way to reach this, the current President in Tanzania, when addressing the new Parliament at the end of 2015, talked of industrialization as key priority of the government during his term of office. For any industrialization to take place innovation is vital. In order to have good innovators, though, stimulation in innovation through the education system is needed. However, the level at which this is articulated in the different curricula is not clear. This paper analyses the extent to which the curriculum for higher learning institutions integrates contemporary development issues and innovation elements. The paper takes as case one of a Development Finance and Investment Planning Programme in the Planning Institute in Tanzania. The Department deals with, among other issues, investment planning. The Department is selected because industrialization is a matter of investment. The curriculum review through content analysis has shown that there is little considerations about development and innovation, facts that can jeopardize industrialization. The paper recommends that the curriculum is revised introducing contemporary development issues and innovation elements.
\end{abstract}

Keywords: Development, Industrialization, Innovation

\section{Introduction}

In recent years, many African countries Tanzania inclusive have demonstrated renewed commitment to transform their economies both socially and economically from agrarian societies into semi industrialized societies so as to shift from low income countries to middle income countries. For any industrialization to take place innovation is vital. In order to have good innovators, though, stimulation in innovation through the education system is needed. However, the level at which this is articulated in the different curricula is not clear. This paper presents the extent to which the curriculum for higher learning institutions integrates innovation and development elements.

This paper begins with a section that presents a link between industrialization and development. This is a crucial section because it theoretically shows that development, at least the modern one, has occurred through industrialization. In the third section, the paper presents an overview of industrialization. The section aims at showing how far Tanzania is in terms of industrialization, clearly pointing out that there is dire need for more industrialization in order to become a middle income country. 
Texila International Journal of Management

Volume 2, Issue 2, Dec 2016

In the third section, the paper deals with the methodology that has been used to collect empirical information. Basically, with the case study of a Department in a Planning institute, the paper makes use of content analysis to establish the level of integration of innovation elements in the curriculum. Innovation is taken from Schumpeter's (1934) theoretical lenses. The fifth section presents the results of the empirical study, followed by another section on the conclusion and recommendations. In the final section, the sixth one, the paper winds up with some suggestions for further study in order to make innovation central in the curriculum for higher learning institutions in order to enhance industrialization.

\section{Industrialization and development}

Industrialization is associated with economic development and has been a hallmark of modernization and national economic power (Brundtland, 2007). Industrialization forms a major objective of the development strategy and government policy for most countries and it is not surprising too that most developing nations have made industrialization a nation priority (Mohammed et. al., 2014), as hardly have any countries developed without industrialization. Industrialization is necessary for development, through industrialization; developing nations like Tanzania are able to realize high economic development like that of the development nations. Szirmai (2009) argues that the sector that uses more intensively machinery and industrial equipment in the production of both consumption and intermediate goods is the leading sectors in the creation and diffusion of technical progress for the whole economy.

Successful industrialization helps create the employment that economies like Tanzania need as they release labour from agriculture, both directly and indirectly by stimulating the development of modern services (Wangwe S. M., et al., 2004). As countries industrialize, workers are pulled out of low productivity agriculture to manufacturing, leading to an increase in overall productivity in the economy as well as an increase in the share of workers employed in better paid jobs in manufacturing as compared to the subsistence income they may obtain in agriculture (Prema C. A., 2015). It is for this reason that industrialization remains the most powerful engine of structural change and modernization. Industrialization of Tanzania is becoming an imperative to support the path of sustainable development characterized by social inclusions and innovation. The main rational for strengthening the Tanzania industrial sector is embedded in the fact that industrialization is the locus of significant innovation that in turn provide opportunities for growth in the rest of the sectors. Even though its share of the Gross Domestic Product (GDP) is still small, the sector is still the engine for modern economy.

\section{Overview of industrialization in tanzania}

The idea of industrializing in Tanzania did not start yesterday. Industrialization was and has been on the main agenda of the first phase government and has remained so to date (Uledi A et al, 2014). The history of industrialization can be traced as far back as the independence. At independence, Tanzania had a very low level of industrialization and was the least industrialized in East African Common Market Partners (Kwan S. Kim, 1986). At that time, they were only 220 industrial establishment in Tanzania employing at least 10 persons each with fixed assets not exceeding TSh200, 000/=. Total employment was about 20,000 persons contributing only 4\% to GDP (Skarstein and Wangwe 1986)

The first serious attempt for Tanzania to influence development of the industrial sector began in the mid1970s, when the country formulated its first industrial policy. This was a 20 year (1975-1995) perspective Basic industrialization strategy (BIS) adopted in 1975 (Wange et al, 2004). The strategy had several goals to achieve that was;

Industrial growth, structural change, employment generation, increased equity, income distribution, increased equity of regional development and workers participation in industry and self reliance.

The strategy emphasized three things that is 1) investments of industries geared towards meeting basic consumer needs; 2 Small scale industries that were to offer employment and 
income generation opportunities and lastly, 3 investments in producer (capital goods) that were assumed to have potential in creating linkages and hence transforming structural transformation (ibid).

The BIS however due to unsatisfactory performance as a result of the mainly serious economic crisis caused by internal constraints and external shocks, was later replaced by Sustainable Industrial Development Policy (SIDP) covering the period of 1996-2020 (URT, 1996). The SIDP was launched during the second half of the 1990's with the purpose of accomplishing the government decision to phase out its involvement in direct investment in productive activities and letting the private sector to become the main player in the economy. SIDP gives priority to employment creation, economic transformation and equitable development and seeks to strike a balance between import substitution and export orientation. SIPD was to be implemented in three phases that is (1996-2000) a phase for rehabilitating and consolidating industrial capacities. Phase one emphasized initiating production of intermediate goods and light capital, phase two (2000-2010) was to generate new capacities in areas with potential for creating competitive advantage through the use of efficient technology and learning process and phase three (2010-20) was to achieve major investments in basic capital industries to ensure consolidation of the industrial structures developed in phase one and two.

Within the same period, Tanzania in 1999 adopted the Tanzania Development Vision 2025. The vision emphasized the role of the industrial sector in the development process of the country. The Tanzania Development Vision (TDV) 2025 (URT,2005a) sets out the new policy framework for the transformation of Tanzania from a least developed country to a middle income country by 2025 through making a shift from agriculture as the main stay of the economy to a semi industrialized economy. In the struggle to achieve the TDV, other strategies were introduced too to help in the realization of the vision including the Long Term Perspective Plan 2011/12 to 2025 (URT, 2010a) with three five year plans. The first Five Year Development Plan (2011/12-2015/16) (URT, 2010b) emphasized industrial development as the foundation for export-led growth; the Export Processing Zones (EPZ) initiated by the Export processing Zones Act (2002) and institutionalized through the Export Processing Zones Authority (EPZA) in 2006. The aim of the EPZs was to attract investment for exportled industrialization in order to increase foreign exchange earnings and employment and to promote domestic processing through adding value to local raw materials. Later the Tanzania Mini-Tiger Plan 2020 (URT, 2005b) was introduced in 2005 to support the implementation of TDV 2025 to replicate the successful development of the manufacturing sector achieved by the Asian tiger's in Tanzania. TDV 2015 is also supported by a number of other policy documents including the Small and Medium Enterprise Development policy 2003 (URT, 2003a), the National Trade Policy 2003 (URT. 2003b). Lastly, the most recent initiative to promote the achievement of TDV 2025 was the Integrated Industrial Development Strategy (URT, 2013).

As a way to reach Tanzania Development Vision 2025, the current President in Tanzania, when addressing the new Parliament at the end of 2015, talked of industrialization as key priority of the government during his term of office. The idea is that manufacturing needs to contribute $40 \%$ of the GDP and generate $40 \%$ of all new jobs by 2020 . For any industrialization to take place innovation is vital. There is a need therefore to realize that the solution of the past decades based on the old economy paradigm of efficient resource accumulation may not be a solution to industrialization. Instead, intangible assets like human resources and intellectual capital are better than traditional assets such as land as the dominant drivers of industrial growth. In order to create an innovative -industrial driven economy, education is key to economic development and important to developing an innovation-driven economy. It is therefore important for Tanzania to leverage on the strategic role of innovation as a means of generating new business ideas that in turn will lead to greater success in industrial development and hence lead to achievement of the 2025 vision as continuously emphasized by the president. In order to achieve this, the education system more especially at 
Texila International Journal of Management

Volume 2, Issue 2, Dec 2016

the higher education needs to create people who are innovative enough for industrialization to happen. In other words, the curriculum design for higher learning institutions must fit country's needs of industrialization. Higher education needs to prepare human resources of the future with skills and knowhow that are needed to plan and manage industries. In order to strengthen industrialization, it is necessary to integrate development issues and innovation elements in the whole education system more especially in the higher education curricula. The innovation process in education should address contents, methodologies, resources and competences. However, the level at which this is articulated in the different curricula is not clear. This paper analyses the extent to which the curricula for higher learning institutions integrates development issues and innovation elements.

\section{Material and methods}

The study has been conducted at the Institute of Rural Development Planning (IRDP) more specifically in the Department of Development Finance and Management Studies. IRDP was established in 1979 by the Act of Parliament No.8 of 1980 as a body corporate, it was to be an important centre for providing opportunities for training of professional personnel of various cadres to meet the planning and plan implementation requirements at different spatial levels.

IRDP is a public institution established to provide training, research and consultancy in the field of rural development planning. Currently, the institute has four academic department offering various programmes as follows: The Department of Regional Development Planning has the following programmes (1) Certificate in Rural Development Planning, (2) Diploma in Development Planning, (3) Bachelor Degree in Regional Development Planning, Bachelor Degree in Development Economics; Postgraduate Diploma in Project Planning and Management and Master Degree in Development Economics; Department of Environmental Planning and Management with three programmes including Bachelor Degree in Environmental Planning and Management, Bachelor Degree in Urban Planning and Postgraduate Diploma in Environmental Planning and Management and Master Degree in Environmental Planning and Management; Department of Population Planning with four programmes including Certificate in Planning and Community Development, Diploma in Planning and Community Development, Bachelor Degree in Planning and Community Development and Bachelor Degree in Population Development Planning and lastly, the Department of Development Finance and Management Studies with four active programmes including Certificate in Development Administration, Diploma in Development Administration, Bachelor Degree in Development Finance and Investment Planning and Bachelor Degree in Human Resource Planning and Management. All the eighteen programmes are accredited by the National Council for Technical Education (NACTE) which has accreditation mandate for all non university higher learning institutions in the country.

From the four departments, the department of Development Finance and Management Studies was purposively selected as it has something directly to do with innovation that is investment, the Development Finance and Investment Planning Programme. The Department was established in 2007 and approved by the Institute's Board in the same year. The Department started to offer its first long-term programme, Bachelor Degree in Development Finance and Investment Planning (BDFIP), in 2008/2009 and later three more programmes were introduced. The Department was born out of the sheer need of the Institute to expand and reach out many clients in its noble goal of contributing to the implementation of national development plans for economic and social development of the people of Tanzania and other developing countries. Mainly, the study concentrates on the department of development finance and investment planning. In order to analyze the extent to which the curricula integrates innovation elements.

The data was analyzed through the use of content analysis. All the courses taught in the program and their respective topics were listed. Then, there was matching of the development and innovation elements with the courses and topics within the courses. The results are provided in terms of frequencies and percentages, in both tables and graphs. 
Content analysis was guided by the elements of development and innovation. With regard to development, a publication "Understanding Development", by Paul Hopper (2012) was instrumental. This is a relatively recent publication, which operationalises development in terms of practical issues. In this publication, there are critical debates about development in the contemporary world, which are, actually, key topics of development drawn from a wide range of case studies across the globe. These issues are, namely:

1. Health

2. Population growth

3. Conflict

4. Security

5. Inequality

6. Poverty

7. Trade

8. Gender

9. Education

10. Aid

11. Debt

12. Sustainability

13. Environment

Understanding Development assisted in finding out the extent to which development is reflected in the modules and the content of the curriculum in the Department.

With regard to innovation, Joseph Schumpeter (1934), who used the concept of "creative destruction" and "new combinations”, was very useful. He looks at innovation as creativity and identifies the following key elements in innovation:

1. Production

2. Invention

3. Market

4. Raw materials

5. Goods

6. Change

The main objective was to analyze the extent to which this kind of Schumpeterian innovation is reflected in the modules taught and the content too.

\section{Results and discussions}

The results provided are subdivided into two. The first part has to do with the extent to which development elements are incorporated in the curriculum. The second part deals with the extent to which innovation is incorporated in the curriculum.

\section{Development in the curriculum}

According to Hopper (2012), the critical debates in development are Health, Population growth, Conflict, Security, Inequality, Poverty, Trade, Gender, Education, Aid, Debt, Sustainability, Environment. When the courses at the higher learning institution are observed in terms of directly addressing these issues, it is found out that out of the 45 courses taught in the Development Finance and Investment Planning Programme, not even one course has direct reference to the issues raised by Hopper (2012).

However, when observations are made with respect to the topics in these courses, it is observed that of the 158 topics, there are 63 (40\%) topics that refer to the development issues as established by Hopper (2012). The presence of the development issues in the topics of the courses in the Development Finance and Investment Planning Programme are provided in Table 1 below: 
Texila International Journal of Management

Volume 2, Issue 2, Dec 2016

Table1. Development Issues in the topics

\begin{tabular}{l|ll}
\hline Development issues & Frequency & Percent \\
\hline Health & 0 & 0 \\
Population growth & 0 & 0 \\
Conflict & 5 & 8 \\
Security & 3 & 5 \\
Inequality & 10 & 16 \\
Poverty & 7 & 11 \\
Trade & 29 & 46 \\
Education & 1 & 2 \\
Gender & 0 & 0 \\
Aid & 1 & 2 \\
Debt & 0 & 0 \\
Environment & 4 & 6 \\
Sustainability & 3 & 5 \\
Total & 63 & 100 \\
\hline
\end{tabular}

(Source: Curriculum of Planning Institute)

Figuratively, the above data can be shown in this Figure 1:

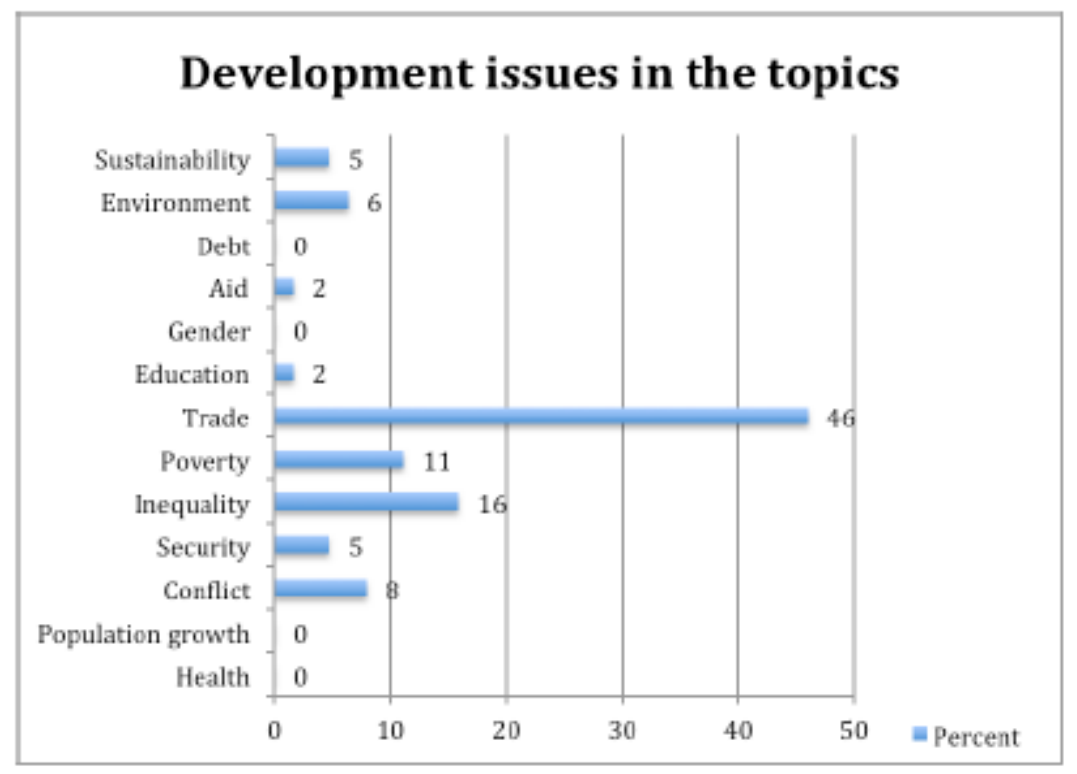

Figure 1: Development issues in the topics

(Source: Curriculum of Planning Institute)

As it can be observed from Table 1 and Figure 1, of the $40 \%$ presence of the topics related to Development, Trade (46\%) is the most frequent topic in the Program, followed by Inequality (16\%) and Poverty (11\%). The others are below 10\% (Sustainability, environment, aid, education, security, and conflict) and more others not even present (debt, gender, population growth, and health). If industrialization has to bring development, it is in terms of enhancing trade, and this trade has to reduce inequalities and poverty (UN, 2015).

The less percentage in sustainability, environment, security and conflict issues, as well as the complete absence of gender aspects, are against common conventional literature about development: development has to happen in a conducive context of sustainable development (UNGA 1987). Sustainable development, in reference to taking care of the environment is 
referred to as "development that meets the needs of the present without compromising the ability of future generations to meet their own needs" (United Nations General Assembly, 1987: 43). Development has to come out in a social environment that is free of conflict and full of security and peace (McCandless \& Karbo 2011). Moreover, gender issues are part and parcel of the development agenda (World Bank 2011).

\section{Innovation in the curriculum}

According to Schumpeter (1934), innovation has to deal with the aspects of production, invention, market, raw materials, goods, and change. When the courses at the higher learning institution are observed in terms of directly addressing these issues, it is found out that 4 (9\%) out of the 45 courses taught in the Development Finance and Investment Planning Programme have direct reference to the elements raised by Schumpeter (1934). These courses are namely: Principles of Marketing and Financial Markets and Institutions for the element of Marketing; Entrepreneurship and Small Business Management for the element of Invention and; Industrial Development Planning for the element of Production.

However, when observations are made with respect to the topics in these courses, it is found out that of the 158 topics, there are 47 (28\%) topics that refer to the innovation elements as established by Schumpeter (1934). The presence of the innovation elements in the topics of the courses in the Development Finance and Investment Planning Programme are provided in Table 2 below:

Table2. Innovation elements in the topics

\begin{tabular}{l|ll}
\hline Innovation elements & Frequency & Percent \\
\hline Production & 27 & 57 \\
Invention & 9 & 19 \\
Market & 5 & 11 \\
Raw materials & 1 & 2 \\
Goods & 1 & 2 \\
Change & 4 & 9 \\
Total & 47 & 100 \\
\hline
\end{tabular}

(Source: Curriculum of Planning Institute)

Figuratively, the above data can be shown in this Figure 2:

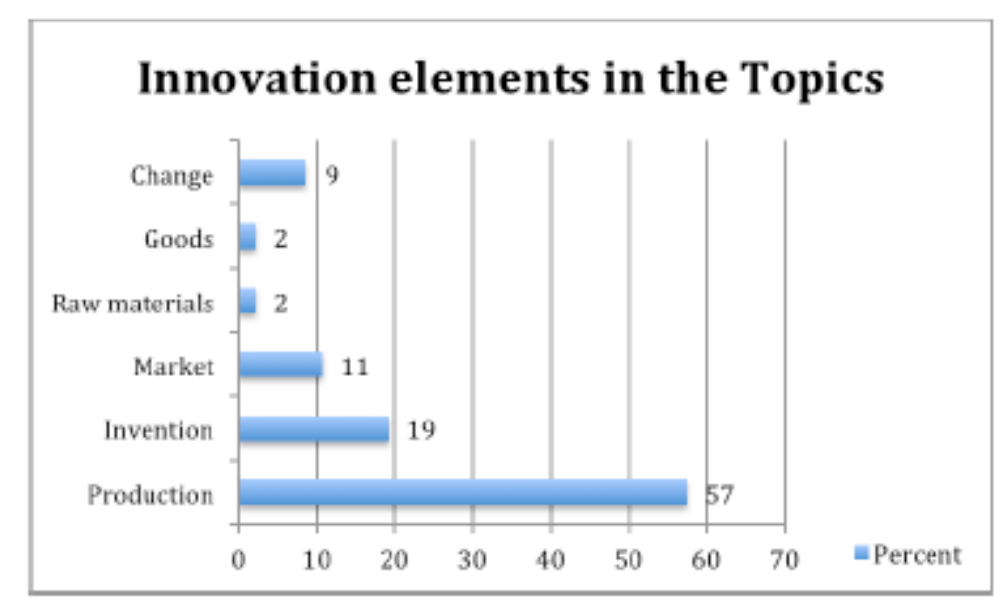

Figure 2: Innovation issues in the topic

As it can be observed from Table 2 and Figure 2, of the 28\% presence of the topics related to innovation, Production (57\%) is the most frequent topic in the Program, followed by Invention (19\%) and Market (11\%); change has got 9\%, while Goods, and Raw materials 
Texila International Journal of Management

Volume 2, Issue 2, Dec 2016

have each $2 \%$. The importance of production, invention, market, and change is clearly stated in the Industrial Development Report 2016 by the United Nations Industrial Development Organization (UNIDO 2015) whereby the issue of technology and innovation in inclusive and sustainable industrial development is give prominence. Much as goods and raw materials receive less attention, they are very important for industrialization (UNIDO 2015).

\section{Conclusion and recommendation}

\section{Summary of findings}

Before I make a conclusion, let me first summarise the key findings.

Out of the 45 courses taught in the Development Finance and Investment Planning Programme, not even one course has direct reference to the development issues in our contemporary society.

Only 63 (40\%) of the 158 topics in the Development Finance and Investment Planning Programme refer to the contemporary development issues.

Of the topics referring to contemporary development, the most frequent topic is Trade (46\%).

Contemporary topics such as debt, gender, population growth, and health have no reference at all in the topics.

Out of the 45 courses taught in the Development Finance and Investment Planning Programme, 4 (9\%) have direct reference to the elements of innovation.

Only 47 (28\%) of the 158 topics refer to the innovation elements.

Of the topics referring to innovation, Production (57\%) is the most frequent topic in the Program.

Goods and Raw materials have the least reference (each 2

\section{Conclusion}

The imminent conclusion from these findings is that the Development Finance and Investment Planning Programme is not viable enough to spearhead the desired industrialization for development process. There is little training in the field of education and innovation. This leads to less insights with regard to how industrialization, that basically needs innovation, can link up with the general processes of development in Tanzania.

\section{Recommendations}

The following are general recommendations that could be applied to any program that needs to address industrialization for development purposes in Tanzania:

The programs need to have clearly articulated courses that have as core the development issues raised in contemporary society. There is need for flexibility in the curriculum: as it might be difficult incorporating development issues as these evolve very fast, then the curriculum should provide room for incorporation of new development issues whenever they arise.

Similarly, the programs need to have clearly articulated courses that have as core the innovation elements.

One final recommendation is that the development issues and the innovation elements are broken down into teachable topics in the programs with the objective of promoting development through industrialization.

\section{Future prospects for research}

This paper has based itself on two theoretical assumptions that innovation leads industrialization, on the one hand, and that industrialization leads to development. Further study could test these assumptions by trying to respond to the following questions:

To what extent does innovation lead to industrialization?

To what extent does industrialization lead to development?

To what extent the curricula of other higher learning institution integrate industrialization. 


\section{Tables and figures}

Table 1: Development issues in the topic

Table 2: Innovation elements in the topic

\section{Figures}

Figure 1: Development issues in the topic

Figure 2: Innovation issues in the topic

\section{Acknowledgements}

My sincere thanks and appreciation goes out to everyone who has helped in putting this article together. I thank my fellow students, for their wonderful discussions through the forums that made me understand more about research methodology. My research instructor Dr. Rheeta Majery for her continued guidance through the module. Thanks too to the two coordinators Kaushika and Yasotha for the continued assistance whenever I was stuck.

Special thanks to my family more especially my husband for his continued financial support, and academic guidance and for the comments that greatly improved my work. Thanks too to my four sons Trevor, Travis, Tresphory and Tressious for understanding that I have started my PHD journey.

\section{References}

[1]. Hopper, P. (2012) Understanding development, Brighton: John Wiley and Sons Ltd

[2]. Hwan S. Kim (1986) Issues and perspectives in Tanzania industrial development with special reference to the role of SADCC, Kellogg Institute

[3]. Lapova, A. and A. Szirmai (2012), Industrialization, employment and poverty, UNU-MERIT Working Paper No. 81.

[4]. Mohammed Sagr Audi, Adamu Mohammed and Alege S. Ola. (2014). Industrialization and Sustainable development. The international Journal of social sciences and humanities, vol 1 (3)

[5]. Morrissey, Oliver and Leyaro, Vincent (2015) Industrial development in Tanzania: reforms, performance, and issues. In: Routledge Handbook of Industry and Development. Routledge international handbooks. Routledge, Abingdon, Oxon, pp. 382-397.

[6]. President John Pombe Magufuli's (2015) speech during the inauguration of the new parliament

[7]. Skarstein, R., and Wangwe, S. (1986). Industrial Development in Tanzania: Some Critical Issues.

Dar es Salaam: Tanzania Publishing House.

[8]. Szirmai, Adam (2009) "Industrialisation as an engine of growth in developing countries, 19502009”. Maastricht: UNU-Merit Working Papers ISSN 1871-9872.

[9]. The Brundtland Report, "Sustainable Development in action," Press Release, United Nations Commission on Sustainable Development, (2007)

[10]. Ulendi A and Mussa L (2014) industrial development and its role in combating unemployment in Tanzania; history, current situation and future prospects. Paper presented at VETA forum in Arusha

[11]. UN (2015) Economic Report on Africa; industrializing through trade, Economic Commission for Africa

[12]. UNIDO (2013), Sustaining Employment Growth: The Role of Manufacturing and Structural Change, Industrial Development Report 2013, Geneva: UNIDO.

[13]. United Nations General Assembly. (1987) Report of the world commission on environment and development: Our common future. Oslo, Norway: United Nations General Assembly, Development and International Co-operation: Environment

[14]. United Nations Industrial Development Organization, 2015. Industrial Development Report 2016. The Role of Technology and Innovation in Inclusive and Sustainable Industrial Development. Vienna: UNIDO

[15]. URT, 1996, sustainable industries development policy 1996-2020, Dar-es salaam; united Republic of Tanzania

[16]. URT, 2003a, Small and Medium Enterprise Development Policy, Dar-es-salaam; United Republic of Tanzania 
Texila International Journal of Management

Volume 2, Issue 2, Dec 2016

[17]. URT, 2003b, The National Trade Policy, Dar-es-salaam; United Republic of Tanzania

[18]. URT, 2005a, Tanzania Development Vision 2025; Dar-es-Salaam; United Republic of Tanzania.

[19]. URT, 2005b, Tanzania-mini-Tiger plan 2020 Dar-es-Salaam; United Republic of Tanzania

[20]. URT, 2010a, Long-term perspective plan, Dar-es-Salaam United Republic of Tanzania

[21]. URT, 2013 Integrated Industrial Development Strategy 2025; Dar-es-Salaam 2025; United Republic of Tanzania

[22]. Wangwe S. M and Dennis Rweyemamu (2004) Challenges towards promoting industrial development in Tanzania paper presented at a workshop to make the 10th anniversary pf ESRF

[23]. Weiss, J. (2013). "Industrial Policy for the Twenty-First Century: Challenges for the Future”, in Szirmai, A., W. Naude and L. Alcorta, Pathways to Industrialisation in the Twenty-First Century: New Challenges and Emerging Paradigms, Oxford: Oxford University Press.

[24]. World Bank. (2011) Gender Equality and Development. Washington DC: World Bank. 